\title{
EFFICACY OF PHEROMONE TRAPPING AND AERIAL SPRAYING OF Bacillus thuringiensis (Bt) FOR CONTROLLING BAGWORM, Metisa plana WALKER (Lepidoptera: Psychidae) IN YONG PENG, JOHOR, MALAYSIA
}

\author{
MOHD NAJIB AHMAD*; NORMAN KAMARUDIN*; SITI NURULHIDAYAH AHMAD*; OTHMAN ARSHAD*; \\ MOHAMED MAZMIRA MOHD MASRI*; RAMLE MOSLIM* and A KUSHAIRI*
}

\begin{abstract}
Recurring bagworm outbreak is a major problem in the oil palm plantation. The continuous use of chemical insecticides to control bagworm outbreaks, the lack of beneficial plants in the plantation to attract natural enemies, and infestation in neighbouring plantations were reported as the contributing factors for bagworm outbreaks. Hence, the aim of this study is to evaluate the efficacy of pheromone trapping application for controlling bagworm, Metisa plana in Mukim Chaah smallholdings in Yong Peng, Johor, Malaysia. The installation of pheromone traps at Mukim Chaah smallholdings was carried out at four different locations for two consecutive generations of $\mathrm{M}$. plana. Results showed that the first and second generations of pheromone trapping at $\mathrm{Kg} \mathrm{Sg}$ Berlian and $\mathrm{Kg}$ Sawah Padi, without the aerial spraying of Bacillus thuringiensis (Bt) have successfully reduced $89 \%$ and $77 \%$ of bagworm population, respectively. Meanwhile, another trapping session conducted at $\mathrm{Kg}$ Temehel and $\mathrm{Kg}$ Seri Sepakat, together with the aerial spraying of $B t$, resulted in the first and second generations of pheromone trapping to successfully reduced $94 \%$ and $85 \%$ of bagworm population, respectively. Together with the aerial spraying of Bt, the two consecutive generations of pheromone trapping application at two different areas in Mukim Chaah smallholdings successfully reduced bagworm population to manageable levels.
\end{abstract}

Keywords: efficacy, pheromone trapping, receptive females.

Date received: 21 April 2016; Sent for revision: 27 April 2016; Received in final form: 14 September 2016; Acepted: 6 October 2016.

\section{INTRODUCTION}

In Malaysia, the major insect pests capable for causing outbreaks in oil palm plantation are bagworms and nettle caterpillars. The economic impact has been a moderate bagworm attack of $10 \%-50 \%$ leaf damage may cause $43 \%$ yield loss (Wood et al., 1972; Basri and Kevan, 1995). Without proper control measures, the population

Malaysian Palm Oil Board, 6 Persiaran Institusi, 43000 Kajang, Selangor, Malaysia.

E-mail: norman@mpob.gov.my of bagworms will increase to above its threshold level, thereby causing serious outbreak. The bagworm is a leaf-eating caterpillar concealed within its carrot-shaped bag, which is constructed from bits of leaflet upon which it feeds (Barlow, 1982). The large numbers of bagworm attack can defoliate the entire palm canopy subsequently resulting in yield loss. The defoliation of palm canopies would result in $30 \%$ reduction of the yield over the next two years (Wood et al., 1972).

As part of an Integrated Pest Management (IPM) programme, pheromone trapping is a simple method for controlling bagworms. Mass trapping 
has been used either in long-term pest management such as codling moth (Cydia pomonella), pink bollworm (Pectinophora gossypiella) and fruit flies, or in the eradication of invasive species [e.g. gypsy moth (Lymantria dispar) and boll weevil (Anthonomus grandis grandis)] (El-Sayed et al., 2006). The strategy to control the bagworm population is by mass trapping the male adults, subsequently limiting their chances to mate with the females for propagating the next generation (Norman et al., 2010; 2011).

Since November 2011, bagworm outbreaks were found and reported in Mukim Chaah smallholdings in districts of Batu Pahat and Labis, Johor, Malaysia, covering 3300 ha. The severity of the infestation was increasing with the total infested area reported in October 2013 at approximately 8916 ha (Mazmira et al., 2015). Thus, the pheromone trapping method for controlling bagworm outbreaks was carried out at two different locations for controlling Metisa plana in 2013.

\section{MATERIALS AND METHODS}

\section{Installation of Traps}

Pheromone mass trapping was carried out for two consecutive generations of $M$. plana at four different areas, starting from 13 - 20 May 2013 (first generation) and 23 - 26 July 2013 (second generation) at $\mathrm{Kg}$ Sg Berlian and $\mathrm{Kg}$ Sawah Padi, and on 24 - 27 September 2013 (first generation) and 27 - 30 November 2013 (second generation) at $\mathrm{Kg}$ Temehel and Kg Sri Sepakat in Mukim Chaah smallholdings, Yong Peng, Johor, Malaysia (Figure 1). The determination of each generation was calculated according to $M$. plana life cycle, which was reported by Basri and Kevan (1995). The amount of traps used during the first and second generations of pheromone trapping conducted at $\mathrm{Kg}$ Sg Berlian and $\mathrm{Kg}$ Sawah Padi in Mukim Chaah smallholdings were 500 and 550 units, respectively. The different number of trap fixed in first and second generations was due to increase of infested areas. Then, the pheromone trapping session was moved to new infested areas, $\mathrm{Kg}$ Temehel and $\mathrm{Kg}$ Sri Sepakat for two consecutive generations of trapping. The amount of traps used during the first and second generations of pheromone trapping conducted at $\mathrm{Kg}$ Temehel and Kg Sri Sepakat in Mukim Chaah smallholdings were 410 and 400 units, respectively. The number of trap was reduced in the second generation due to some areas have recovered, as an effect from the first generation trapping.

The installation of traps commenced at the onset of emergence of male adults in May 2013. Females or pupal samples were evaluated based on the emergence of adults and receptive female (Mohd Rizuan et al., 2011). The female pupa is always larger than the male (Norman et al., 2011). Receptivity of the female was determined by the opening of the anterior end of the pupae bag plus the intermittent protrusion of the female's head and thorax from this opening (Basri and Kevan, 1995; Norman and Othman, 2006). Female will stay receptive for about nine days and closed the anterior end of the pupae bag after this period.

A pheromone trap was made by inserting and stretching a white colour plastic bag, $20 \times 30$ inches in between two 2-m long wooden poles. Each plastic was evenly sprayed with polybutene glue (Chemi Bond, Malaysia). Each trap was baited with four receptive bagworm females, with two females at each hole on the plastic (Figure 2). Fifteen traps were placed in three transects (five traps per transect) along the non-harvesting paths within a hectare of the bagworm-infested plot. The distance between each trap was about $20 \mathrm{~m}$ (Norman et al., 2011).

\section{Aerial Spray Operation}

The aerial spray of Bacillus thuringiensis, MPOB Bt1 product, Ecobac-1 (EC) for controlling second

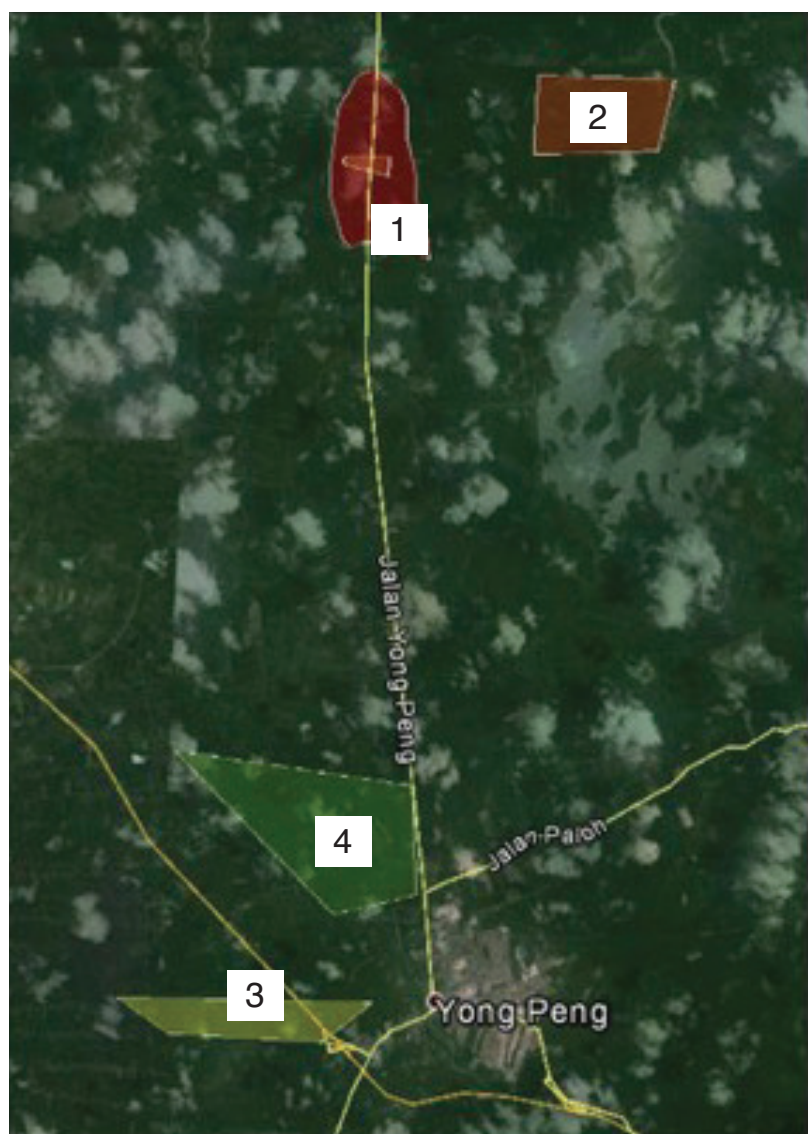

Note: 1 - Kg Sri Sepakat, 2 - Kg Sg Berlian, 3 - Kg Sawah Padi and 4 - Kg Temehel.

Figure 1. GPS map showing location of two consecutive generations of pheromone trapping conducted at two different areas in Mukim Chaah smallholdings, Yong Peng, Johor, Malaysia. 


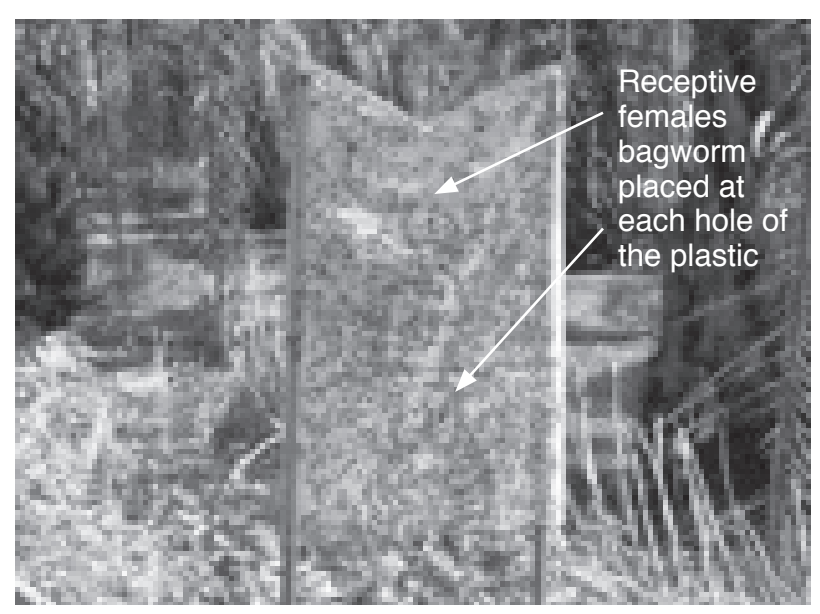

Figure 2. Pheromone trap installed using receptive females of bagworm.

generation of $M$. plana population was conducted at $\mathrm{Kg}$ Sg Berlian, Kg Sawah Padi, Kg Temehel and Kg Sri Sepakat in Mukim Chaah smallholdings, Yong Peng, Johor, Malaysia between 28 October 8 November 2013. The total infested area treated with Ecobac-1 (EC) was 8916 ha. During treatment preparation, 40 litres of Ecobac-1 (EC) was mixed with 1000 litres of water in the aircraft's tank. The aircraft model, AgCat was used during aerial spray operation under IPM programme.

\section{Bagworm Census after Trapping}

Trapping activity took three to seven days to be completed for each session. Therefore, the larval population in the trapped area was censused to determine the density of the bagworm, number of trapping rounds required and the number of traps to be installed in the next trapping application.

\section{Data Analysis}

Data on mortality was analysed using one-way analysis of variance (ANOVA) run on SPSS software version 11.5. When ANOVA result achieved was significant, the means were separated by the Least Significant Difference (LSD) test at $\mathrm{P}<0.05$ using the same software. The histogram was plotted with standard error using SigmaPlot version 11.0.

\section{RESULTS AND DISCUSSION}

\section{Pheromone Trapping Session at Kg Sg Berlian}

From Table 1, the first generation of trapping captured 388.8 moths per trap (MPT) or $18.5 \mathrm{MPT}$ per day at 21 days after trap (DAT). In the second generation of trapping session, results showed that the average male moths caught were $82.5 \mathrm{MPT}$ or 3.9 MPT per day, which was $79 \%$ less compared to the first trapping session. The two consecutive generations of pheromone trapping session had reduced the subsequent total population of live bagworm as in Figure 3. Prior to the first trapping session (Table 2), the mean live larvae population recorded was 3.7 larvae per frond (LPF) at stages 6 and 7, and the total live bagworm population recorded was 52.9 total bagworms per frond. However, after six weeks of trapping, the increment of mean live larvae numbers was observed from 3.7 LPF (before trapping) to 104.5 LPF (after trapping), with $96 \%$ increment. This scenario could be attributed to successful mating of the females and the existing of stages 6 (1.2 LPF) and 7 (2.5 LPF) larvae (Table 2) which were observed before the trapping started.

Subsequently, the next generation (second generation) of live bagworm population decreased for two months after the first trapping session, with the mean of 18.7 bagworms per frond (BPF) recorded on 23 July 2013 (before second generation of trapping). The decrease of live bagworm could be attributed by weather conditions (Hasber et al., 2012). The second generation of trapping session resulted in moderate reduction of total live bagworm numbers, $69 \%$. The average live larvae and total bagworm observed before trapping session was 1.3 LPF and 18.7 total $\mathrm{BPF}$, respectively. Again, stages 6 and 7 larvae population was observed with the average of $0.2 \mathrm{LPF}$ and 1.0 LPF, respectively. Nevertheless, at 6 weeks after trapping (WAT), the number of total bagworm decreased to 5.4 total BPF and the mean live larvae increased to 5.4 LPF (Table 2). The increase of larvae population was likely due to the existence of stages 6 and 7 larvae before trapping which resulted in the formation of live

\section{TABLE 1. EFFECT OF RECEPTIVE M. plana FEMALES IN ATTRACTING MALE MOTHS AFTER TWO CONSECUTIVE PHEROMONE TRAPPING SESSIONS AT KG SG BERLIAN, MUKIM CHAAH SMALLHOLDINGS}

\begin{tabular}{lccc}
\hline Generations/dates of recording & & Male moths trapped at 21 DAT \\
\cline { 2 - 4 } & Range & Mean/trap & Mean/trap/day \\
\hline 1 (3 June 2013) & $0-3352$ & $388.8 \pm 26.8 \mathrm{a}$ & $18.5 \pm 1.3 \mathrm{a}$ \\
2 (14 August 2013) & $0-857$ & $82.5 \pm 6.2 \mathrm{~b}$ & $3.9 \pm 0.3 \mathrm{~b}$ \\
\hline
\end{tabular}

Note: Different letters in row indicate significant difference at $\mathrm{P}<0.05$ after Least Significant Difference (LSD) test. Data was recorded at 21 days after trapping (DAT). 
females and successful mating, contributing to emergence of larvae in the next generation, as indicated in Table 2. This result may also be attributed to incorrect timing of receptive females collected and used during second generation of the trapping session. Norman and Othman (2006) reported that the effective female receptivity period was about nine days. After that, the effect of attracting male moths will decrease drastically.

In conclusions, the two consecutive pheromone trapping sessions conducted at $\mathrm{Kg} \mathrm{Sg}$ Berlian from May to July 2013 were able to reduce mean live bagworm population from 52.9 BPF at 0 WAT (13 May 2013) of the first generation to 5.8 BPF at 6 WAT (3 September 2013) of the second generation, with high reduction of the bagworm population observed, $89 \%$ (Table 2).

\section{Pheromone Trapping Session at Kg Sawah Padi}

From Table 3, the first generation of trapping captured 165.6 MPT or 7.9 MPT per day at 21 DAT. In the second generation of trapping session, result showed that the mean male moths caught were 26.3 MPT or 1.3 MPT per day, which was $84 \%$ less compared to the first trapping session. The two consecutive generations of pheromone trapping session had reduced the subsequent population of total live bagworm as in Figure 3. Prior to the first trapping session (Table 4), the mean live larvae population recorded was $0.4 \mathrm{LPF}$ at stage 7 , and the total live bagworm population recorded was 23.2 total. However, after six weeks of trapping, the increment of mean live larvae numbers was observed from 0.4 LPF (before trapping) to 37.3 LPF (after trapping), with 99\% increment. This scenario could be attributed to successful mating of the females and the existing stage 7 (0.4 LPF) larvae
(Table 4) which were observed before the trapping started.

Subsequently, the next generation (second generation) of live bagworm population decreased two months after the first trapping session, with the mean of 12.1 BPF. The decrease of live bagworm could be attributed to weather conditions (Hasber et al., 2012). The second generation of trapping session resulted in the reduction of total live bagworm numbers, 55\%. The mean live larvae and total bagworm observed before trapping session was $0.8 \mathrm{LPF}$ and 12.1 total BPF, respectively. Again, stages 6 and 7 larvae population was observed with the mean of $0.2 \mathrm{LPF}$ and $0.6 \mathrm{LPF}$, respectively (Table 4). Nevertheless, at 6 WAT, the number of total bagworm decreased to 5.4 total BPF and the mean live larvae increased to 5.4 LPF (Table 4). The increase of larvae population was likely due to the existence of stages 6 and 7 larvae before trapping which resulted in the formation of live females and successful mating, contributing to high emergence of larvae in the next generation, as indicated in Table 4. This result may also be attributed to incorrect timing of receptive females collected and used during second generation of the trapping session. Norman and Othman (2006) reported that the effective female receptivity period was about nine days. After that, the effect of attracting male moths will decrease drastically.

In conclusions, the two consecutive pheromone trapping sessions conducted at $\mathrm{Kg}$ Sawah Padi from May to July 2013 was able to reduce the mean live bagworm population from 23.2 BPF at 0 WAT (13 May 2013) of the first generation to below threshold level, 5.4 BPF at 6 WAT (3 September 2013) of the second generation, with $77 \%$ reduction of the bagworm population (Figure 4 and Table 4).

Average male moth trapped per trap per day and average live larvae and pupae population subjected to pheromone trapping activities in May and July 2013 at Kg Sg Berlian, Mukim Chaah smallholdings

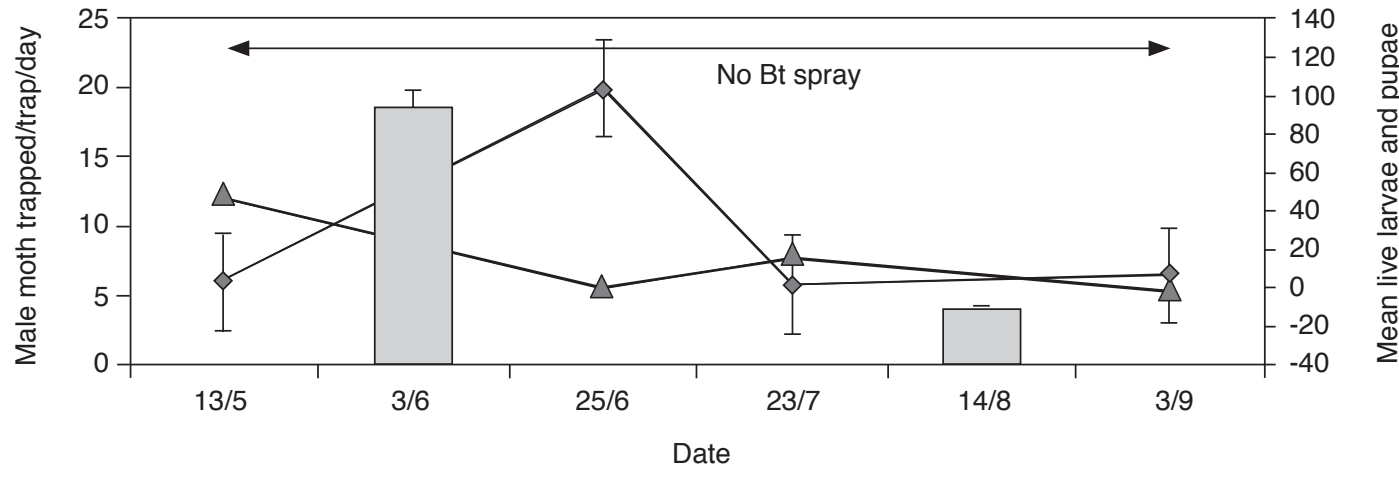

Figure 3. Changes in the population density of average live larvae and pupae after two consecutive pheromone trapping sessions, May 2013 - July 2013 at Kg Sg Berlian, Mukim Chaah smallholdings. 
TABLE 2. DYNAMIC OF BAGWORM POPULATION OBSERVED IN THE FIRST AND SECOND GENERATIONS OF PHEROMONE TRAPPING SESSION AT KG SG BERLIAN, MUKIM CHAAH SMALLHOLDINGS

\begin{tabular}{|c|c|c|c|c|c|c|c|}
\hline \multirow{2}{*}{$\begin{array}{l}\text { Generation/ } \\
\text { palm No., n }\end{array}$} & \multirow{2}{*}{$\begin{array}{l}\text { Time of } \\
\text { census }\end{array}$} & \multicolumn{2}{|c|}{ Total larvae, LPF } & \multicolumn{2}{|c|}{ Pupae, PPF } & \multicolumn{2}{|c|}{ Total bagworm (larvae + pupae), BPF } \\
\hline & & Range & Mean/stage & Range & Mean & Range & Mean \\
\hline \multirow{2}{*}{$\begin{array}{l}\text { First } / \\
n=60\end{array}$} & $\begin{array}{l}\text { Before } \\
\text { trapping } \\
\text { (13 May } \\
2013)\end{array}$ & $0-14$ & $\begin{array}{c}1.2 \pm 0.2-\mathrm{L} 6 \\
2.5 \pm 0.3-\mathrm{L} 7 \\
\mathbf{3 . 7} \pm \mathbf{0 . 4}\end{array}$ & $1-129$ & $49.1 \pm 4.2$ & $1-130$ & $52.9 \pm 4.1$ \\
\hline & $\begin{array}{l}\text { After } \\
\text { trapping } \\
\text { (25 June } \\
2013 \text { ) }\end{array}$ & $0-361$ & $\begin{array}{c}0.1 \pm 0.1-\mathrm{L} 2 \\
31.6 \pm 3.5-\mathrm{L} 3 \\
49.8 \pm 4.6-\mathrm{L} 4 \\
22.6 \pm 3.6-\mathrm{L} 5 \\
1.8 \pm 0.9-\mathrm{L} 6 \\
\mathbf{1 0 4 . 5} \pm \mathbf{1 0 . 8}\end{array}$ & $0-0$ & 0 & $0-361$ & $104.5 \pm 10.8$ \\
\hline \multirow{2}{*}{$\begin{array}{l}\text { Second/ } \\
n=60\end{array}$} & $\begin{array}{l}\text { Before } \\
\text { trapping } \\
\text { (23 July } \\
\text { 2013) }\end{array}$ & $0-5$ & $\begin{array}{c}0.2 \pm 0.1-\mathrm{L} 6 \\
1.0 \pm 0.1-\mathrm{L} 7 \\
\mathbf{1 . 3} \pm \mathbf{0 . 1}\end{array}$ & $0-37$ & $17.4 \pm 1.1$ & $0-42$ & $18.7 \pm 1.2$ \\
\hline & $\begin{array}{c}\text { After } \\
\text { trapping } \\
\text { (3 September } \\
\text { 2013) }\end{array}$ & $0-23$ & $\begin{array}{c}1.2 \pm 0.2-\mathrm{L} 2 \\
3.8 \pm 0.4-\mathrm{L} 3 \\
0.8 \pm 0.1-\mathrm{L} 4 \\
\mathbf{5 . 8 \pm 0 . 7}\end{array}$ & $0-0$ & 0 & $0-23$ & $5.8 \pm 0.7$ \\
\hline
\end{tabular}

Note: LPF - larvae per frond. PPF - pupae per frond. BPF - bagworms per frond.

TABLE 3. EFFECT OF RECEPTIVE $M$. plana FEMALES IN ATTRACTING MALE MOTHS AFTER TWO CONSECUTIVE PHEROMONE TRAPPING SESSIONS AT KG SAWAH PADI, MUKIM CHAAH SMALLHOLDINGS

\begin{tabular}{lccc}
\hline Generations/dates of recording & \multicolumn{3}{c}{ Male moths trapped at 21 DAT } \\
\cline { 2 - 4 } & Range & Mean/trap & Mean/trap/day \\
\hline 1 (3 June 2013) & $0-1460$ & $165.6 \pm 43.3 \mathrm{a}$ & $7.9 \pm 2.1 \mathrm{a}$ \\
2 (14 August 2013) & $0-102$ & $26.3 \pm 9.9 \mathrm{~b}$ & $1.3 \pm 0.5 \mathrm{~b}$ \\
\hline
\end{tabular}

Note: Different letters in row indicate significant difference at $\mathrm{P}<0.05$ after Least Significant Difference (LSD) test. Data was recorded at 21 days after trapping (DAT).

\section{Pheromone Trapping Session at Kg Temehel}

In September 2013, the trapping session was carried out at a new infested area, $\mathrm{Kg}$ Temehel, located $35 \mathrm{~km}$ from the previous trapping location. For the first generation of trapping session, the mean male moths caught was 307.7 MPT or 14.7 MPT per day. For the second generation, the number of male moths caught per trap was $51.5 \mathrm{MPT}$ or $2.5 \mathrm{MPT}$ per day. The number of moths caught in the second generation was found to decrease significantly $(\mathrm{P}<0.05), 83 \%$ as compared to the first generation male moths trapped (Table 5).

In the first generation of trapping session, result showed that the total live bagworm numbers reduced significantly, $48 \%$, one month after trapping session (Figure 5 and Table 6). The total bagworm observed before trapping session was 64.5 total BPF and at 6 WAT, the number decreased to 33.5 total BPF (Table 6). Although the stages $6(0.3$ LPF) and 7 (1.7 LPF) larvae were observed before the trapping session, the declining trend could be attributed to the correct timing of receptive females collected (Norman and Othman, 2006) during the trap fixing session. The trapping session for the first generation was conducted during early morning, at 7 am. According to Mohd Rizuan et al. (2011), the receptive female (unfertilised/virgin stage), female with yellowish eggs (fresh eggs of gravid female) and female with brownish eggs (matured eggs of gravid female) mated twice at period between 7.45 $-8.21 \mathrm{am}$.

Subsequently, the next generation (second generation) of live bagworm population decreased 
Average male moth trapped per trap per day and average live larvae and pupae population subjected to pheromone trapping activities in May and July 2013 at Kg Sg Sawah Padi, Mukim Chaah smallholdings
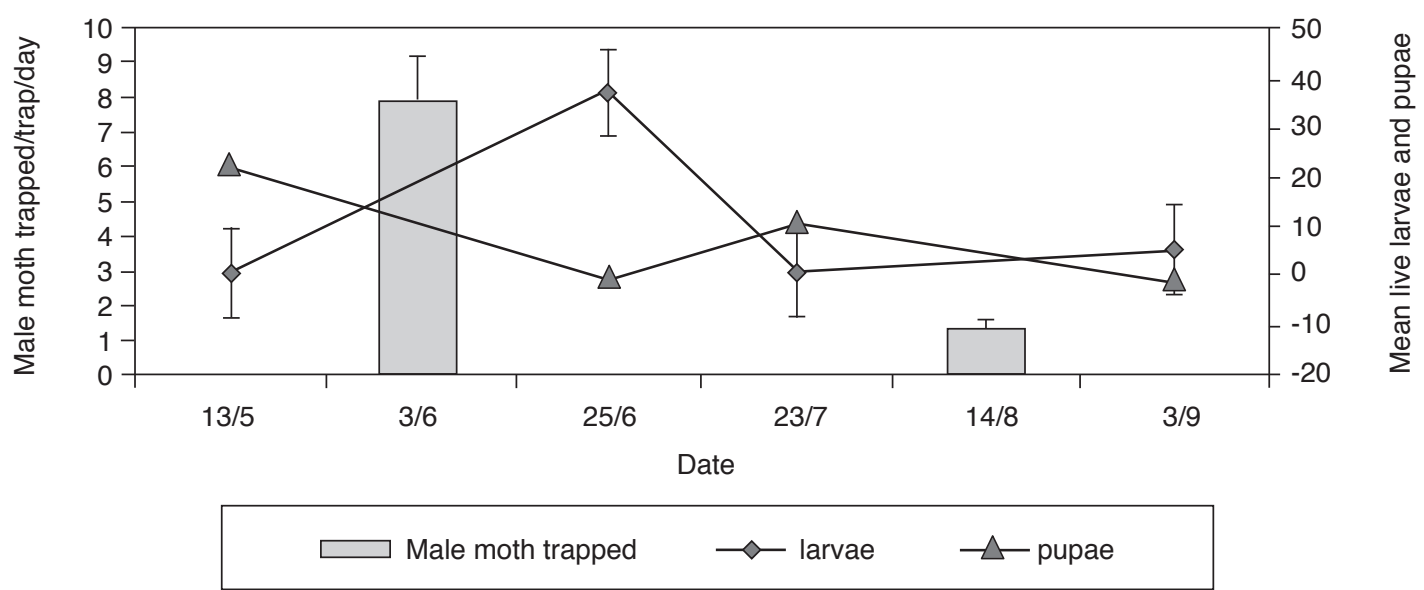

Figure 4. Changes in the population density of average live larvae and pupae after two consecutive pheromone trapping sessions, May 2013 - July 2013 at Kg Sawah Padi, Mukim Chaah smallholdings, Johor, Malaysia.

TABLE 4. DYNAMIC OF BAGWORM POPULATION OBSERVED IN THE FIRST AND SECOND GENERATIONS OF PHEROMONE TRAPPING SESSION AT KG SAWAH PADI, MUKIM CHAAH SMALLHOLDINGS

\begin{tabular}{|c|c|c|c|c|c|c|c|}
\hline \multirow{2}{*}{$\begin{array}{l}\text { Generation/ } \\
\text { palm No., } \mathbf{n}\end{array}$} & \multirow{2}{*}{$\begin{array}{l}\text { Time of } \\
\text { census }\end{array}$} & \multicolumn{2}{|c|}{ Total larvae, LPF } & \multicolumn{2}{|c|}{ Pupae, PPF } & \multicolumn{2}{|c|}{ Total bagworm (larvae + pupae), BPF } \\
\hline & & Range & Mean/stage & Range & Mean & Range & Mean \\
\hline \multirow{2}{*}{$\begin{array}{l}\text { First } \\
\mathrm{n}=10\end{array}$} & $\begin{array}{l}\text { Before } \\
\text { trapping } \\
\text { (13 May } \\
2013)\end{array}$ & $0-1$ & $\begin{array}{c}0.4 \pm 0.2-\mathrm{L} 7 \\
\mathbf{0 . 4} \pm \mathbf{0 . 2}\end{array}$ & $4-52$ & $22.8 \pm 5.2$ & $4-52$ & $23.2 \pm 5.3$ \\
\hline & $\begin{array}{l}\text { After } \\
\text { trapping } \\
\text { (25 June } \\
\text { 2013) }\end{array}$ & $0-108$ & $\begin{array}{c}0.1 \pm 0.1-\mathrm{L} 2 \\
12.7 \pm 5.2-\mathrm{L} 3 \\
21.5 \pm 8.9-\mathrm{L} 4 \\
3.0 \pm 3.1-\mathrm{L} 5 \\
\mathbf{3 7 . 3} \pm \mathbf{1 4 . 8}\end{array}$ & $0-0$ & 0 & $0-108$ & $37.3 \pm 14.8$ \\
\hline \multirow{2}{*}{$\begin{array}{l}\text { Second/ } \\
n=10\end{array}$} & $\begin{array}{l}\text { Before } \\
\text { trapping } \\
\text { (23 July } \\
2013)\end{array}$ & $0-3$ & $\begin{array}{c}0.2 \pm 0.1-\mathrm{L} 6 \\
0.6 \pm 0.2-\mathrm{L} 7 \\
\mathbf{0 . 8} \pm \mathbf{0 . 3}\end{array}$ & $0-21$ & $11.3 \pm 2.5$ & $0-24$ & $12.1 \pm 2.7$ \\
\hline & $\begin{array}{c}\text { After } \\
\text { trapping } \\
\text { (3 September } \\
\text { 2013) }\end{array}$ & $0-17$ & $\begin{array}{c}1.3 \pm 0.8-\mathrm{L} 2 \\
4.0 \pm 1.2-\mathrm{L} 3 \\
0.1 \pm 0.1-\mathrm{L} 4 \\
\mathbf{5 . 4 \pm 2 . 0}\end{array}$ & $0-0$ & 0 & $0-17$ & $5.4 \pm 2.0$ \\
\hline
\end{tabular}

Note: LPF - larvae per frond. PPF - pupae per frond. BPF - bagworms per frond.

TABLE 5. EFFECT OF RECEPTIVE $M$. plana FEMALES IN ATTRACTING MALE MOTHS AFTER TWO CONSECUTIVE PHEROMONE TRAPPING SESSIONS AT KG SAWAH PADI, MUKIM CHAAH SMALLHOLDINGS

\begin{tabular}{lccc} 
Generations/dates of recording & \multicolumn{3}{c}{ Male moths trapped at 21 DAT } \\
\cline { 2 - 4 } & Range & Mean/trap & Mean/trap/day \\
\hline 1 (17 October 2013) & $0-1896$ & $307.7 \pm 23.8 \mathrm{a}$ & $14.7 \pm 1.1 \mathrm{a}$ \\
2 (17 December 2013) & $0-1110$ & $51.3 \pm 22.3 \mathrm{~b}$ & $2.5 \pm 1.1 \mathrm{~b}$ \\
\hline
\end{tabular}

Note: Different letters indicate significant difference at $\mathrm{P}<0.05$ after Least Significant Difference (LSD) test. Data was recorded at 21 days after trapping (DAT). 
from 33.5 BPF on 6 November 2013 (after first trapping) to $21.5 \mathrm{BPF}$ on 27 November 2013 (before second trapping) (Table 6), with $36 \%$ reduction of bagworm population. The decrease of live bagworm could be attributed to weather conditions (Hasber et al. 2012) and the effect of aerial spraying of Bt product on 28 October 2013 (Figure 5). The second generation of trapping session resulted in a high reduction of total live bagworm numbers, $81 \%$ from 27 November 2013 to 7 January 2014 (Table 6). The mean live larvae and total bagworm observed before trapping session was $0.5 \mathrm{LPF}$ and 21.5 total BPF, respectively. Again, stages 6 and 7 larvae population was observed with the average of $0.1 \mathrm{LPF}$ and $0.5 \mathrm{LPF}$, respectively. Nevertheless, at $6 \mathrm{WAT}$, the number of total bagworm decreased

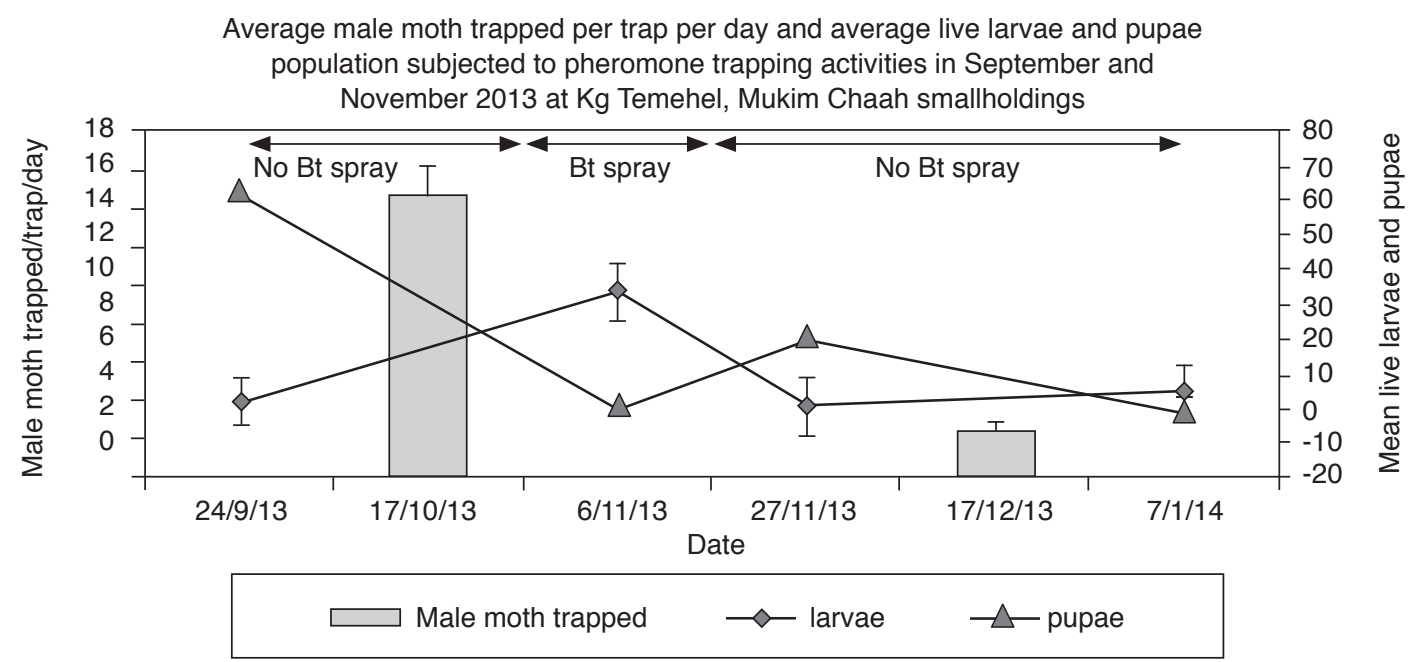

Figure 5. Changes in the population density of average live larvae and pupae after two consecutive pheromone trapping sessions, September 2013 - November 2013 at Kg Temehel.

TABLE 6. DYNAMIC OF BAGWORM POPULATION OBSERVED IN THE FIRST AND SECOND GENERATIONS OF PHEROMONE TRAPPING SESSION AT KG TEMEHEL, MUKIM CHAAH SMALLHOLDINGS, JOHOR, MALAYSIA

\begin{tabular}{|c|c|c|c|c|c|c|c|}
\hline \multirow{2}{*}{$\begin{array}{l}\text { Generation } \\
\text { /palm No., } \mathbf{n}\end{array}$} & \multirow{2}{*}{$\begin{array}{l}\text { Time of } \\
\text { census }\end{array}$} & \multicolumn{2}{|c|}{ Total larvae, LPF } & \multicolumn{2}{|c|}{ Pupae, PPF } & \multicolumn{2}{|c|}{ Total bagworm (larvae + pupae), BPF } \\
\hline & & Range & Mean/stage & Range & Mean & Range & Mean \\
\hline \multirow{2}{*}{$\begin{array}{l}\text { First } \\
\mathrm{n}=70\end{array}$} & $\begin{array}{c}\text { Before } \\
\text { trapping } \\
\text { (24 September } \\
\text { 2013) }\end{array}$ & $0-6$ & $\begin{array}{c}0.3 \pm 0.1-\mathrm{L} 6 \\
1.7 \pm 0.1-\mathrm{L} 7 \\
\mathbf{2 . 1} \pm \mathbf{0 . 2}\end{array}$ & $10-212$ & $62.4 \pm 5.3$ & $10-213$ & $64.5 \pm 5.4$ \\
\hline & $\begin{array}{c}\text { After } \\
\text { trapping } \\
\text { (6 November } \\
\text { 2013) }\end{array}$ & $0-341$ & $\begin{array}{c}0.6 \pm 0.1-\mathrm{L} 2 \\
12.6 \pm 2.6-\mathrm{L} 3 \\
16.0 \pm 5.0-\mathrm{L} 4 \\
4.2 \pm 1.9-\mathrm{L} 5 \\
\mathbf{3 3 . 5} \pm 8.8\end{array}$ & $0-0$ & 0 & $0-341$ & $33.5 \pm 8.8$ \\
\hline \multirow{2}{*}{$\begin{array}{l}\text { Second / } \\
n=30\end{array}$} & $\begin{array}{c}\text { Before } \\
\text { trapping } \\
\text { (27 November } \\
\text { 2013) }\end{array}$ & $0-3$ & $\begin{array}{c}0.1 \pm 0-\text { L6 } \\
0.5 \pm 0.1-\text { L7 } \\
\mathbf{0 . 5} \pm \mathbf{0 . 1}\end{array}$ & $0-85$ & $20.9 \pm 3.1$ & $0-88$ & $21.5 \pm 3.1$ \\
\hline & $\begin{array}{c}\text { After } \\
\text { trapping } \\
\text { (7 January } \\
\text { 2014) }\end{array}$ & $0-14$ & $\begin{array}{c}0.1 \pm 0-\mathrm{L} 2 \\
0.2 \pm 0.1-\mathrm{L} 3 \\
26.1 \pm 0.5-\mathrm{L} 4 \\
1.2 \pm 0.3-\mathrm{L} 5 \\
0.1 \pm 0.1-\mathrm{L} 6 \\
\mathbf{4 . 1} \pm \mathbf{0 . 8}\end{array}$ & $0-0$ & 0 & $0-14$ & $4.1 \pm 0.8$ \\
\hline
\end{tabular}

Note: LPF - larvae per frond.

PPF - pupae per frond.

$\mathrm{BPF}$ - bagworms per frond. 
to 4.1 total BPF and the mean live larvae increased to 4.1 LPF (Table 6). The increase of larvae population was likely due to the existence of stages 6 and 7 larvae population, 0.5 LPF (mean) before trapping which contributed to low emergence of larvae in the next generation, as indicated in Table 6 . This result may be attributed to correct timing of receptive females collected and used during second generation of the trapping session. The high reduction observed during second generation of trapping might due to precise timing of trapping. As a result, at 6 WAT, the mean live larvae recorded was only $4.1 \mathrm{LPF}$ as compared to the first generation of pheromone trapping session, 33.5 LPF at 6 WAT (Table 6).

The two consecutive pheromone trapping sessions conducted at $\mathrm{Kg}$ Temehel from September to November 2013 was able to reduce mean live bagworm population from $64.5 \mathrm{BPF}$ at 0 WAT (24 September 2013) of the first generation to 4.1 BPF at 6 WAT (7 January 2014) of the second generation, with $94 \%$ reduction of the bagworm population (Table 6).

\section{Pheromone Trapping Session at Kg Seri Sepakat}

In September 2013, another trapping session was carried out at a new infested area, Kg Sri Sepakat. For the first generation of trapping session, the mean male moths caught was 114.7 MPT or 5.5 MPT per day. For the second generation, the number of male moths caught per trap was 36.0 MPT or 1.7 MPT per day. The number of moths caught in the second generation was found to decrease significantly $(\mathrm{P}<0.05), 69 \%$ as compared to the first generation male moths trapped (Table 7).

In the first generation of trapping session, result showed that the total live bagworm numbers reduced significantly, $73 \%$, one month after trapping session (Figure 6 and Table 8). The total bagworm observed before trapping session was 23.3 total BPF and at $6 \mathrm{WAT}$, the number decreased to $6.3 \mathrm{BPF}$ (Table 8). Although the stages 6 (0.1 LPF) and 7 (1.0 LPF) larvae were observed before the trapping session, the declining trend could be attributed to the correct timing of receptive females collected (Norman and Othman, 2006) during the trap fixing session.

TABLE 7. EFFECT OF RECEPTIVE M. plana FEMALES IN ATTRACTING MALE MOTHS AFTER TWO CONSECUTIVE PHEROMONE TRAPPING SESSIONS AT KG SRI SEPAKAT, MUKIM CHAAH SMALLHOLDINGS

\begin{tabular}{lccc}
\hline \multicolumn{1}{c}{ Generations/month } & \multicolumn{3}{c}{ Male moths trapped } \\
\hline & Range & Mean/trap & Mean/trap/day \\
\cline { 2 - 4 } 1 (24-27 September 2013) & $0-1008$ & $114.7 \pm 32.1 \mathrm{a}$ & $5.5 \pm 1.5 \mathrm{a}$ \\
2 (27-30 November 2013) & $0-270$ & $36.0 \pm 15.2 \mathrm{~b}$ & $1.7 \pm 0.7 \mathrm{~b}$ \\
\hline
\end{tabular}

Note: Different letters indicate significant difference at $\mathrm{P}<0.05$ after Least Significant Difference (LSD) test. Data was recorded at 21 days after trapping (DAT).

\section{Average male moth trapped per trap per day and average live larvae and pupae population subjected to pheromone trapping activities in September and November 2013 at Kg Sri Sepakat, Mukim Chaah smallholdings}

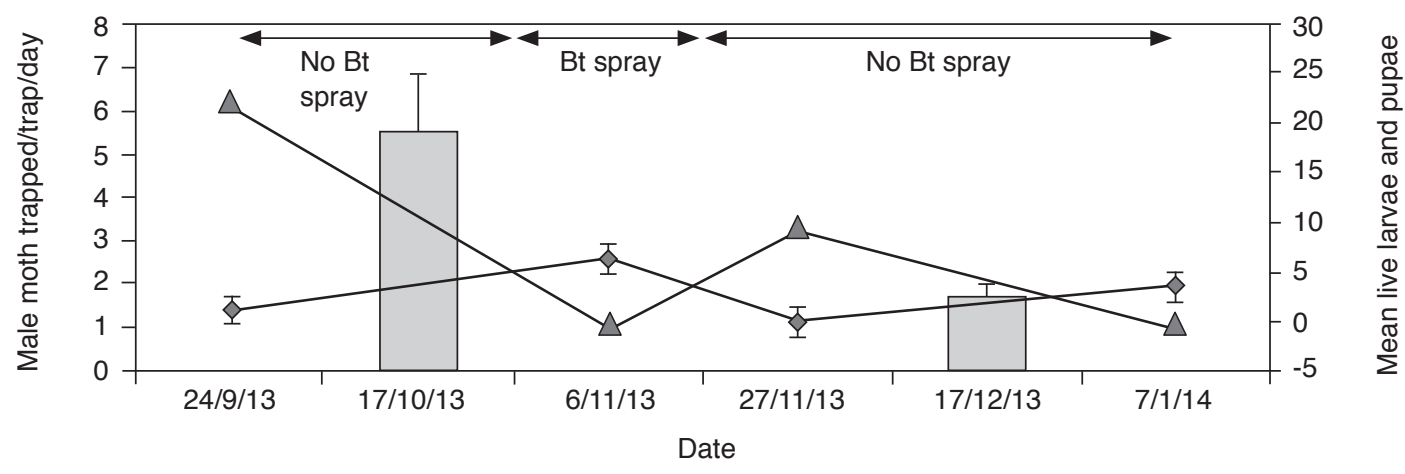

$\square$ Male moth trapped $\sim$ - larvae $\quad \backsim$ pupae

Figure 6. Changes in the population density of average live larvae and pupae after two consecutive pheromone trapping sessions, September 2013 - November 2013 at Kg Sri Sepakat. 
Subsequently, the next generation (second generation) of live bagworm population increased from 6.3 BPF on 6 November 2013 (after first trapping) to 9.6 BPF on 27 November 2013 (before second trapping) (Table 8). The increase of live bagworm could be attributed to the male moths which escaped the trapping had successful mating in the previous trapping session (first generation of trapping - 24 September 2013) and ballooning process from neighbouring area (Hasber et al., 2012). The second generation of trapping session resulted in a reduction of total live bagworm numbers, $64 \%$ from 27 November 2013 to 7 January 2014 (Table 8). The mean live larvae and total bagworm observed before trapping session was 0 LPF and 9.6 total BPF, respectively. In the second generation of trapping, no live larvae were recorded before trapping started. Subsequently, at 6 WAT, the number of total bagworm decreased to $3.5 \mathrm{BPF}$ and the mean live larvae increased to 3.5 LPF (Table 8). The increase of larvae population was likely due to the male moths which escaped the trapping had successful mating, as indicated in Table 8. However, the total bagworm population was reduced by $64 \%$ in the second generation of trapping and this result may be attributed to correct timing of receptive females collected and used during second generation of the trapping session. The reduction observed during second generation of trapping might due to precise timing of trapping. As a result, at $6 \mathrm{WAT}$, the mean live larvae recorded was only 3.5 LPF as compared to previous trapping session. 6.3 LPF (Table 8).
The two consecutive pheromone trapping sessions conducted at $\mathrm{Kg}$ Sri Sepakat from September to November 2013 were able to reduce the mean live bagworm population from $23.3 \mathrm{BPF}$ at 0 WAT (24 September 2013) of the first generation to below threshold level, 3.5 BPF at 6 WAT (7 January 2014 ) of the second generation, with $85 \%$ reduction of the bagworm population (Table 8).

As a comparison, the fixing of pheromone traps without involving Bt spray at $\mathrm{Kg} \mathrm{Sg}$ Berlian and $\mathrm{Kg}$ Sawah Padi could reduce $89 \%$ and $77 \%$ of the bagworm population, respectively, from the first generation (May 2013) to the second generation (July 2013) of pheromone trapping sessions (Table 9). Meanwhile, the pheromone trapping sessions involving Bt spray at $\mathrm{Kg}$ Temehel and $\mathrm{Kg}$ Sri Sepakat resulted in $94 \%$ and $85 \%$ reduction of the bagworm population from the first generation (September 2013) to the second generation (November 2013) of pheromone trapping sessions (Table 9). The decline at four different areas could be attributed to the correct timing of receptive females collected (Norman and Othman, 2006) during the trap fixing session and minimal number of late larvae existed prior to the start of the trapping session (Tables 2, 4, 6 and 8). On 28 October 2013, the aerial spraying operation using Bt product was carried out at $\mathrm{Kg}$ Temehel and Kg Seri Sepakat (Table 9). Subsequently, the average bagworm reduction at both places was slightly higher, $89.5 \%$ as compared to $\mathrm{Kg} \mathrm{Sg}$ Berlian and Kg Sawah Padi, with 83\% reduction and without involving Bt spray. Furthermore, the mean

TABLE 8. DYNAMIC OF BAGWORM POPULATION IN THE FIRST AND SECOND GENERATIONS OF PHEROMONE TRAPPING SESSION AT KG SRI SEPAKAT, MUKIM CHAAH SMALLHOLDINGS

\begin{tabular}{|c|c|c|c|c|c|c|c|}
\hline \multirow{2}{*}{$\begin{array}{l}\text { Generation } \\
\text { /palm No., n }\end{array}$} & \multirow{2}{*}{$\begin{array}{l}\text { Time of } \\
\text { census }\end{array}$} & \multicolumn{2}{|c|}{ Total larvae, LPF } & \multicolumn{2}{|c|}{ Pupae, PPF } & \multicolumn{2}{|c|}{ Total bagworm (larvae + pupae), BPF } \\
\hline & & Range & Mean/stage & Range & Mean & Range & Mean \\
\hline \multirow{2}{*}{$\begin{array}{l}\text { First } \\
\mathrm{n}=10\end{array}$} & $\begin{array}{c}\text { Before } \\
\text { trapping } \\
\text { (24 September } \\
\text { 2013) }\end{array}$ & $0-3$ & $\begin{array}{c}0.1 \pm 0.1-\mathrm{L} 6 \\
1.0 \pm 0.3-\mathrm{L} 7 \\
\mathbf{1 . 1} \pm \mathbf{0 . 3}\end{array}$ & $8-43$ & $22.2 \pm 3.6$ & $9-44$ & $23.3 \pm 3.7$ \\
\hline & $\begin{array}{c}\text { After } \\
\text { trapping } \\
\text { (6 November } \\
\text { 2013) }\end{array}$ & $0-14$ & $\begin{array}{c}0.1 \pm 0.1-\mathrm{L} 2 \\
5.1 \pm 1.3-\mathrm{L} 3 \\
1.1 \pm 0.4-\mathrm{L} 4 \\
\mathbf{6 . 3} \pm \mathbf{1 . 5}\end{array}$ & $0-0$ & 0 & $0-14$ & $6.3 \pm 1.5$ \\
\hline \multirow{2}{*}{$\begin{array}{l}\text { Second/ } \\
n=10\end{array}$} & $\begin{array}{c}\text { Before } \\
\text { trapping } \\
\text { (27 November } \\
\text { 2013) }\end{array}$ & $0-0$ & 0 & $0-28$ & $9.6 \pm 3.1$ & $0-28$ & $9.6 \pm 3.1$ \\
\hline & $\begin{array}{c}\text { After } \\
\text { trapping } \\
\text { (7 January } \\
\text { 2014) }\end{array}$ & $0-12$ & $\begin{array}{c}0.3 \pm 0.2-\mathrm{L} 3 \\
1.9 \pm 0.6-\mathrm{L} 4 \\
1.3 \pm 0.6-\mathrm{L} 5 \\
\mathbf{3 . 5} \pm \mathbf{1 . 3}\end{array}$ & $0-0$ & 0 & $0-12$ & $3.5 \pm 1.3$ \\
\hline
\end{tabular}

Note: PPF - pupae per frond. BPF - bagworms per frond. 
TABLE 9. BAGWORM REDUCTION AFTER TWO CONSECUTIVE PHEROMONE TRAPPING SESSIONS AT FOUR DIFFERENT AREAS

\begin{tabular}{|c|c|c|c|}
\hline Trapping area & Date of trapping & $\begin{array}{c}\text { Percent reduction of } \\
\text { bagworms, } \% \text { (two } \\
\text { consecutive } \\
\text { generations of } M . \text { plana) }\end{array}$ & Remarks \\
\hline Kg Sg Berlian & May and July 2013 & 89 & Not involved Bt spray \\
\hline Kg Sawah Padi & & 77 & \\
\hline Kg Temehel & September and November 2013 & 94 & Involved Bt spray \\
\hline Kg Seri Sepakat & & 85 & \\
\hline
\end{tabular}

live larvae population observed was decreased to 33.5 LPF and 6.3 LPF at Kg Temehel and Kg Sri Sepakat, respectively, on 6 November 2013 due to aerial spray effect.

\section{CONCLUSION}

Pheromone trapping application at four different areas in Mukim Chaah smallholdings has successfully reduced the bagworm population to a manageable level. The correct timing of pheromone trapping based on the receptivity of the live bagworm females ensured the effectiveness of pheromone trapping. The correct stage of bagworm prior to the start of the pheromone trapping session is important to bring down the bagworm population in subsequent generation. Mass trapping of the male bagworm moths can complement IPM for bagworms by reducing the bagworm population in subsequent generations.

\section{ACKNOWLEDGEMENT}

The authors would like to thank the DirectorGeneral of MPOB for permission to publish this article. Special thanks to TUNAS South Zone 1 for their technical and logistic support and Mukim Chaah smallholders for allowing MPOB to fix the pheromone traps in their areas. Last but not least to the staff of Entomology and Ecological Research laboratory, MPOB who involved in initiating and conducting the pheromone trapping activity.

\section{REFERENCES}

BARLOW, H S (1982). An Introduction to the Moths of South East Asia. Art Printing Works Sdn Bhd, Kuala Lumpur. 305 pp. Chapter 2 PSU Knowledge Bank kb.psu.ac.th/psukb/ bitstream/2010/5855/1/313724.pdf

BASRI, M W and KEVAN, P G (1995). Life history and feeding behaviour of the oil palm bagworm,
Metisa plana Walker (Lepidoptera: Psychidae). Elaeis, 7(1): 18-35. MPOB, Bangi. portal.mpob.gov.my/ html/01_r\&d/01_b01_05a_03.html

EL-SAYED, A M; SUCKLING, D M; WEARING, C $\mathrm{H}$ and BYERS, J A (2006). Potential of mass trapping for long-term pest management and eradication of invasive species. J. Economic Entomology, 99(5): 1550-64. www.ars.usda.gov/research/ publications / Publications.htm?seq_no_115=...

HASBER, S and NOOR HISHAM, H (2012). Evaluation of several chemical control approaches against bagworm, Metisa plana Walker (Lepidoptera: Psychidae) in FELDA oil palm plantations. The Planter, 88 (1040): 785-799. Evaluation of Several Chemical Control Approaches against Bagworm ...www.researchgate.net/ publication / 236019714 Evaluation_of_Several...

MAZMIRA, M M M; NAJIB, M A; NORHAZWANI, K; NORMAN, $\mathrm{K}$ and SITI RAMLAH, A A (2015). Implementing an Integrated Pest Management (IPM) program for bagworm control in oil palm smallholdings in Johor. Proc. of the PIPOC 2015 International Palm Oil Congress - Oil Palm: Powering the World, Sustaining the Future. p. 15-20. www.researchgate.net/ publication/368708846 IMPLEMENTING_AN_INTEGRATED_PEST..

MOHD RIZUAN, Z A; NOOR HISHAM, H; SUKRI, T I and ABU HASSAN, A (2011). Field evaluation of mating behavior of male moth towards receptive female of the bagworm, Metisa plana (Lepidoptera: Psychidae). Proc. of the PIPOC 2011 International Palm Oil Congress: Palm Oil - Fortifying and Energizing the World. p. 71-74. www.researchgate.net/ publication/256605694_FIELD_EVALUATION OF...

NORMAN, K and OTHMAN, A (2006). Potential of using the pheromone trap for monitoring and controlling the bagworm, Metisa plana Wlk (Lepidoptera: Psychidae) in a smallholder plantation. J. Asia Pasific Entomology, 9(3): 281-285. Pheromone mass trapping of bagworm moths, 
Metisa plana Walker ... www.sciencedirect.com/ science/article/ pii/S1226861509001058

NORMAN, K; SITI NURULHIDAYAH, A; OTHMAN, A and BASRI, M W (2010). Pheromone mass trapping of bagworm moths, Metisa plana Walker (Lepidoptera:Psychidae), for its control in mature oil palms in Perak, Malaysia. J. Asia Pasific Entomology, 13(2): 101-106. DOI:10.1016/j. aspen.2009.11.003.

NORMAN, K; SITI NURULHIDAYAH, A and OTHMAN, A (2011). A sticky vane trap for mass trapping of the bagworm, Metisa plana in oil palm. $M P O B$ Information Series No. 487. A Sticky Vane trap for Mass trapping Metisa plana in oil palm palmoilis. mpob.gov.my/publications/TOT/TT-487.pdf

WOOD, B J; CORLEY, R H V and GOH, K H (1972). Studies on the effect of pest damage on oil palm yield. Advances in Oil Palm Cultivation. Incorporated Society of Planters. p. 360-379. Pest Control in Malaysia's Perennial Crops: A Half Century Perspective ... link.springer.com/article/10.1023/ B:IPMR.0000027501.91697.49 